\title{
On the avoidance of voiced sibilant affricates
}

\author{
Marzena Żygis \\ Zentrum für Allgemeine Sprachwissenschaft, Berlin
}

In this paper it is argued that several typologically unrelated languages share the tendency to avoid voiced sibilant affricates. This tendency is explained by appealing to the phonetic properties of the sounds, and in particular to their aerodynamic characteristics. On the basis of experimental evidence it is shown that conflicting air pressure requirements for maintaining voicing and frication are responsible for the avoidance of voiced affricates. In particular, the air pressure released from the stop phase of the affricate is too high to maintain voicing which in consequence leads to a devoicing of the frication part.

\section{Introduction}

Phonemic inventories of the world's languages show various types of gaps which are accounted for by appealing to the phonetic properties of the sounds under question. These properties are in turn inevitably connected with the anatomy and functioning of the human vocal tract during speech production. For example, it has been widely shown that the voiced velar stop [g] does not occur frequently in the phonemic inventories of the world's languages in comparison to their voiced counterpart [k] (see Maddieson 1984, Boersma 1988). A possible explanation of this gap pertains to the difficulty in maintaining optimal conditions for voicing due to a short cavity behind the constriction. ${ }^{1}$

The present investigation expands the list of sounds which are avoided

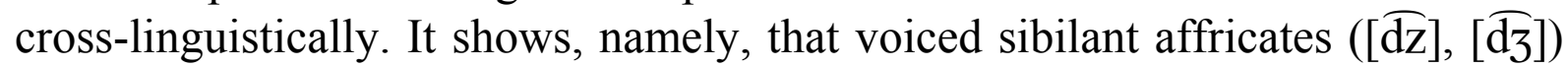
tend to be eliminated from phonemic inventories. At the same time, their voiceless counterparts $[\widetilde{\mathrm{ts}}],[\mathrm{t}\}]$ show a different behavior: the affricates are stable and they create a part of many phonemic inventories. This observation also holds for languages with a complete voicing contrast in coronal stops and fricatives; see Slavic inventories discussed in section 2.

1 For other gaps in phonemic inventories see Maddieson (1984). 
That voiced sibilant affricates are avoided is also confirmed by phonological processes which convert these sounds into others. In some languages we observe a productive devoicing of affricates even in a word-initial position (see section 3 for examples).

Explaining the avoidance of voiced affricates is a challenge for any phonological theory. Several phonological approaches to voicing contrasts, including those dealing with features, are not able to account for this gap; see e.g. Lombardi (1994, 1999), Iverson \& Salmons (1995, 2003), Steriade (1997), Avery \& Idsardi (2001), Wetzels \& Mascaro (2001), Kehrein (2002).

How can we explain this cross-linguistic avoidance of voiced sibilant affricates? In this paper, phonetic evidence is taken into consideration. It is argued that voiced affricates are exposed to an aerodynamic conflict: the air pressure required for maintaining voiced frication is often too high due to the high pressure conditions in the stop phase. This conclusion is evidenced by experimental results presented in section 5 .

The paper is organized as follows. In section 2 several inventories from various language families are provided illustrating the gap of voiced affricates in phonemic systems. Further evidence for the cross-linguistic tendency to avoid voiced sibilant affricates is provided in section 3 where examples of phonological processes converting voiced sibilants to other sounds are discussed. Section 4 deals with a typology of voicing based on 451 language inventories according to which voiced affricates are the least frequent phonemes among coronal obstruents. The remaining part of the study is devoted to a presentation and discussion of a piece of experimental evidence showing that aerodynamic relations or even aerodynamic conflicts in the production of voiced affricates are responsible for their avoidance. Section 6 concludes.

\section{Phonemic inventories}

The investigation of several typologically unrelated languages reveals a systematic gap in the phonemic inventories of the world's languages: voiced sibilant affricates are not attested.

The presentation starts with Slavic languages, followed by a discussion of languages from Romanic and Germanic language families. Examples from Asiatic and Arabic languages are provided as well.

Slavic languages undoubtedly serve to advance the hypothesis that voiced affricates are avoided. In almost all Slavic inventories these phonemes are either not present or they occur in a very limited number of (foreign) words. Phonemic inventories of languages representing West, East and South Slavic family are presented in Table 1, 2, and 3 respectively. 
Table 1: Czech phonemic system.

\begin{tabular}{|l|l|l|l|l|l|l|}
\hline & \multicolumn{2}{|l|}{ dental/alveolar } & \multicolumn{2}{|l|}{ palatoalveolar } & \multicolumn{2}{|c|}{ palatal } \\
\hline fricative & s & z & $\int$ & 3 & & \\
\hline affricate & $\overline{\mathrm{ts}}$ & & $\overline{\mathrm{t}}$ & & & \\
\hline stop & $\mathrm{t}$ & $\mathrm{d}$ & & & $\mathrm{c}$ & $\mathrm{f}$ \\
\hline
\end{tabular}

Table 2: Russian phonemic system.

\begin{tabular}{|c|c|c|c|c|c|c|c|c|}
\hline & \multicolumn{4}{|c|}{ dental } & \multicolumn{2}{|c|}{ retroflex } & \multicolumn{2}{|c|}{ palatoalveolar } \\
\hline fricative & S & $\mathrm{Z}$ & $S^{j}$ & $\mathrm{Z}$ & $\mathrm{S}$ & $\mathrm{Z}$ & $\int^{\mathrm{j}}:$ & $\left(3^{\mathrm{j}}:\right)$ \\
\hline affricate & $\overparen{t S}$ & & & & & & $\overline{\mathrm{t} \int^{j}}$ & \\
\hline stop & $\mathrm{t}$ & d & $t^{2}$ & d & & & & \\
\hline
\end{tabular}

Table 3: Bulgarian phonemic system.

\begin{tabular}{|c|c|c|c|c|c|}
\hline & \multicolumn{3}{|c|}{ dental } & \multicolumn{2}{|c|}{ palatoalveolar } \\
\hline fricative & S & $\underline{Z}$ & $S_{n}^{j} \quad Z_{n}^{j}$ & J & 3 \\
\hline affricate & $\overline{t S S}$ & & $\overline{\mathrm{tS}}^{\mathrm{j}}$ & $\overline{\mathrm{t} t}$ & $(\overline{\mathrm{d}} 3)$ \\
\hline stop & $\mathrm{t}$ & $\underset{n}{d}$ & $\underline{t}^{\mathrm{j}}$ & & \\
\hline
\end{tabular}

A common denominator of Czech and Russian phonemic inventories is the absence of voiced affricates. In Bulgarian, the voiced affricate $/ \bar{d} /$ is found in a few foreign words. At the same time, in all three languages coronal fricatives and stops display a voicing contrast.

An analysis of other Slavic inventories leads to similar results. Slovene displays a voicing contrast in fricatives and stops, but not in affricates. As far as the latter are concerned, $/ \overline{\mathrm{dz}} /$ is not attested. The palato-alveolar $/ \overline{\mathrm{d} z} /$ is only found in words of foreign origin. For this reason its phonemic status is rejected by some scholars; see e.g. Dalewska-Greń (2002). A similar scenario is repeated in Czech. A voicing contrast is shown by stops and fricatives, while the affricate phonemes include only the voiceless segments $\overleftarrow{\mathrm{ts}} /$ and $/ \mathrm{t \textrm {f }} /$, see Kučera (1961:24).

In several Serbian and Croatian dialects, it is the voiced affricate $/ \mathrm{dz} /$ that is often missing; see, for example, the Jekavian dialect of Eastern Herzegovina, the Young Ikavian dialect, the Istrian Ikavian dialect, and a number of Slavonian dialects, see Ivić (1958).

In Upper Sorbian, the voiced counterparts of $\overparen{\mathrm{tS}_{\mathrm{n}}} /$ and $/ \mathrm{ts}_{\mathrm{n}}^{\mathrm{j}} /$ are not attested, whereas the contrast between $/ \widetilde{\mathrm{tg}} /$ and $/ \overline{\mathrm{d}} /$ is phonemically represented. By 
contrast, in Lower Sorbian, no voiced affricates are attested despite the

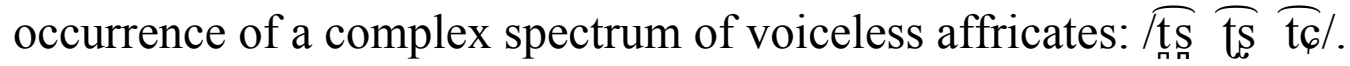

Although the Macedonian inventory seems to be complete, the symmetry between $/ \overparen{\mathrm{dz}} /$ and $/ \widehat{\mathrm{ts}} /$ as well as $/ \widehat{\mathrm{dz}} /$ and $/ \widehat{\mathrm{tg}} /$ is questionable. The voiced affricate $/ \overline{\mathrm{d} z} /$ is mainly found in words of foreign origin, particularly in those borrowed from Turkish. Dalewska-Greń (2002:93) observes that $/ \overline{\mathrm{dz}} / \mathrm{n} /$ occurs in a few native morphemes. Hence, Macedonian also shows a voicing contrast with respect to affricates, but the presence of voiced affricates, especially $/ \overline{\mathrm{dz}} /$, is rather marginal.

Prima facie, the inventories of Belorussian and Ukrainian (especially its western dialects) show a voicing contrast in sibilant affricates. However, Zilyns'kyj (1979:114) points out that voiced affricates, especially $/ \widehat{\mathrm{dz}} /, / \widehat{\mathrm{dz}}^{\mathrm{j}} /$ and $/ \overline{d z} /$, occur only marginally in western Ukrainian. They are present in a few

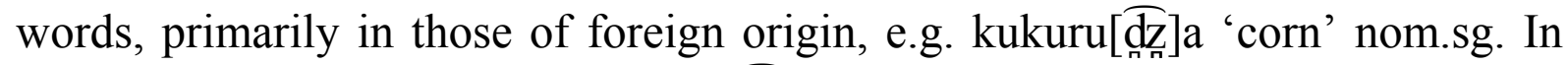
western dialects, the alveolo-palatal / $\overline{\mathrm{d} z /}$ appears in loanwords from Polish, e.g.

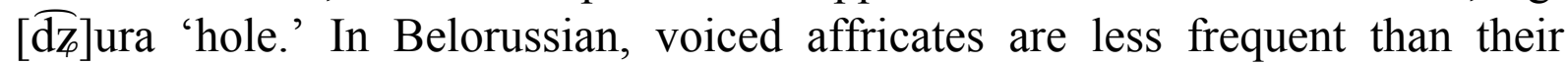
voiceless counterparts. This observation pertains especially to $/ \overline{\mathrm{dz}} /$, which is found especially in onomatopoetic words and loanwords, e.g. ks'on[ [dz] 'priest.'

According to Dalewska-Greń (2002), in two Slavic languages, Polish and Slovak, voiceless and voiced affricates are attested and, moreover, well represented in the vocabulary. However, a closer inspection of the vocabulary reveals that the occurrence of voiced affricates is very limited. In Polish the affricate $/ \overline{\mathrm{dz}} /$ occurs in a very few proper names in word-initial position. Similarly, the occurrence of [ $[\overline{\mathrm{dz}}]$ is limited to a few foreign words, again in word-initial position. The two affricates are well represented in word-medial positions when they appear as outputs of morpho-phonological processes. A very similar conclusion pertains to Slovak voiced affricates which are found in word-medial positions, and their presence is mostly morphologically conditioned.

Finally, it has to be stressed that the voiced affricates did occur in all Slavic languages but they either completely disappeared or converted to other sounds; see Zygis (2006) for a detailed discussion.

Romanic languages do not prefer voiced affricates either. The only difference between Slavic and Romance languages is that the former also display voicing contrast in stops and fricatives, whereas the latter show voicing symmetries in stops only. For example, the Romanian coronal inventory contains the following obstruents: /t d s $\int \widehat{\mathrm{ts}} \overparen{\mathrm{tg}} /$. Similarly, in the inventory of Galician, voiced fricatives and voiced affricates are not attested. The systems consists of $/ \mathrm{t} \mathrm{d}$ s $\int \widehat{\mathrm{tg}} /$.

There are at least two Germanic languages relevant for the present discussion. In German, $/ \mathrm{t} d \mathrm{~d} \quad \mathrm{~s} \mathrm{z} \overparen{\mathrm{ts}} \widehat{\mathrm{t} \int} /$ are part of the phonemic inventory 
while the voiced affricate $/ \bar{d} /$ only occurs in words of foreign origin (see Hall 1992). But even there they tend to be devoiced, see section 3 for examples. In Yiddish, the voicing opposition in coronal obstruents is symmetrical except for affricates which are limited to the voiceless $\overline{\mathrm{t} \mathrm{J}} /$.

In African languages, it can be observed that voiceless segments are generally predominant. In Northern Soto, voiced affricates create a gap. In addition, a voiced $/ \mathrm{d} /$ and $/ \mathrm{z} /$ are not attested. Consider the tableau in Table 4.

Table 4: Northern Soto phonemic system.

\begin{tabular}{|l|l|l|l|l|l|}
\hline & \multicolumn{2}{|l|}{ dental/alveolar } & \multicolumn{2}{l|}{ palatoalveolar } \\
\hline fricative & $\mathrm{s}$ & & & $\int$ & 3 \\
\hline affricate & $\overparen{\mathrm{ts}}$ & & $\widetilde{\mathrm{ts}}^{\mathrm{h}}$ & $\widetilde{\mathrm{t} S}$ & $\widetilde{\mathrm{t}}^{\mathrm{h}}$ \\
\hline stop & $\mathrm{t}$ & & $\mathrm{t}^{\mathrm{h}}$ & & \\
\hline
\end{tabular}

In Ekegusii, a language spoken in Kenya, the coronal phonemic inventory is constituted by voiceless segments / $\mathrm{s} \widehat{\mathrm{t}} \overline{\mathrm{l}} /$ only. In Chingoni (southern Tanzania), the voicing system is symmetrical in fricatives, but not in stops and affricates: $/ \mathrm{t}$ $\overline{\mathrm{t} \int} \mathrm{s} \mathrm{z} /$. In summary, the investigation of sibilant inventories of several languages shows that affricates show an asymmetry in voicing: voiced affricates are considerably less frequent than their voiceless counterparts. In many languages their status is either marginal, i.e. they occur in foreign words only, as for example in Slovene or Bulgarian, or they do not occur at all, as in Russian or Yiddish.

\section{Phonological processes}

The avoidance of voiced affricates is also evidenced by phonological processes attested cross-linguistically. In many languages the voiced affricates convert to other sounds, most frequently to fricatives and glides. Furthermore, it is also observed that the affricates devoice not only domain-finally but also in other, e.g. word-initial or intervocalic positions. Of special importance for the present study are (i) changes not conditioned by context which could possibly blur inherent properties of affricates and (ii) changes which are not motivated by internal language-specific factors as e.g. improving phonemic contrast. Most processes presented below are in accordance with these two conditions.

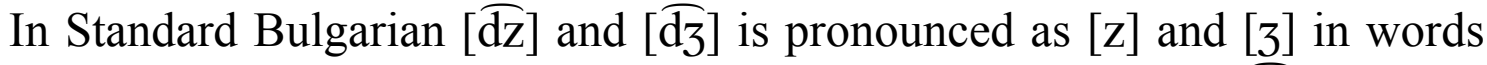
adopted from Bulgarian dialects, respectively. For example, $/ \overline{\mathrm{dz}} / \mathrm{vezda}$ is pronounced as [z]vezda 'star' in Standard Bulgarian. Dalewska-Greń (2002:96) stresses that $/ \overline{\mathrm{d}} /$ is found in foreign words and that it changes to [3] in colloquial speech. 
In Czech, loan words containing the affricates $[\overline{\mathrm{dz}}]$ and $[\overline{\mathrm{d}}]$ are converted to a sequence of a stop followed by a fricative, i.e. to [dz] and [d3]. For example, [d]3]udo 'judo' is pronounced as [d]]udo, see Kučera (1961:33), Short (1993:457). But this sequence is also found in native words [d3]ban 'jug' and [d3]ber 'tub' and at some morpheme boundaries, e.g. in po[dz]emi 'underground' a sequence $[\mathrm{dz}]$ rather than the affricate $[\overline{\mathrm{dz}}]$ is pronounced (Short 1993:457).

In literary Upper Sorbian, $/ \overline{d z} /$ it is replaced by $[z]$, e.g. in the declension of substantives ending in -ga. For example Jadwi[g]a 'proper name, nom.sg' appears as Jadwi[dz]e 'acc.sg.' The latter form converts to Jadwi[z]e; see Schuster-Šewc (1999:38).

In Romance languages, voiced sibilant affricates frequently convert to

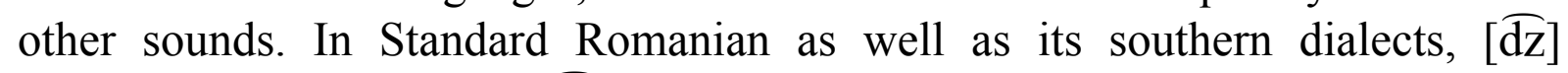

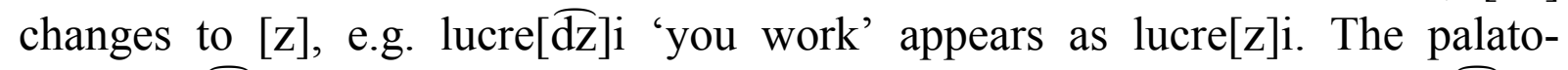

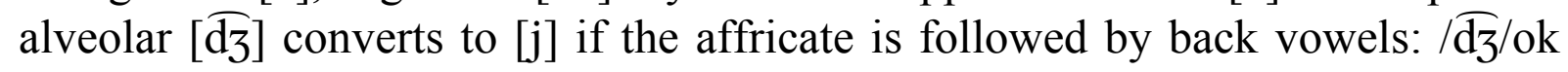
'game' is pronounced as [j] ok. In Florentine Italian, both voiced and voiceless affricates convert to fricatives in the word-initial position $\left(\overline{\mathrm{d}_{3}}, \overline{\mathrm{t} f} \rightarrow 3, \mathrm{~S} / \# \_\right.$). For example /dz/orni 'days' is realised as [3]orni; see Gianneli \& Savoia (1979).

In the Graulhet dialect of Occitan (Western Lengadocian, near Tolosa and Albi), $[\widehat{[t}]$ and $\left[\widehat{\mathrm{d}_{3}}\right]$ from Standard Occitan merge into a single affricate [ts]. Thus, Standard Occitan [ $\overline{\mathrm{d}} 3$ ] orn 'day' is pronounced as [tsun] in Graulhet dialect (Lieutard 2004).

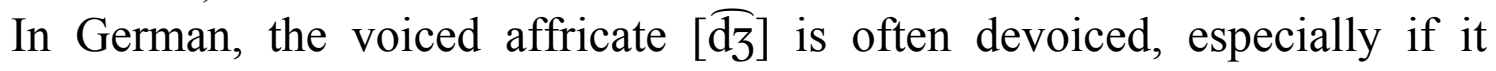
occurs in the word-initial position (and not intervocalically). The foreign words

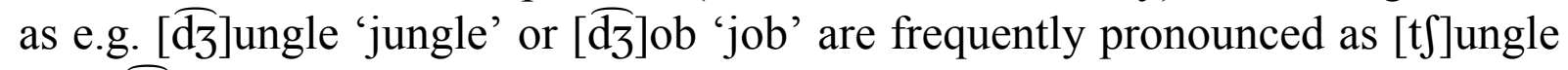
and [t]] ob by both Southern and Northern German speakers. The initial devoicing pertains, however, not only to affricates. Stops tend to be devoiced as well and sibilant fricatives are always voiced in word-initial position.

In Gulf Arabic, the voiced affricate [ $\overline{\mathrm{d}} 3]$ alternates with a palatalized $\left[\mathrm{g}^{\mathrm{j}}\right]$ and $[\mathrm{j}]$ depending on the context (but also on the dialect). The alternation [ $\overline{\mathrm{d}} 3]$ $\left[\mathrm{g}^{\mathrm{j}}\right]$ is found in words which have a historical [g] usually followed by a front

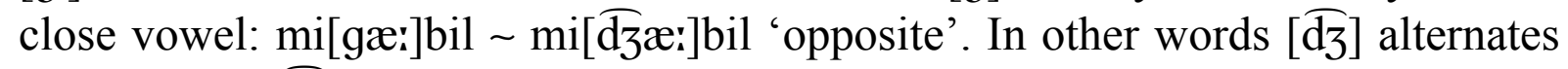
with [j], e.g. [ד্dzæ:]r [jæ:]r 'neighbour'; see Holes (1990:262).

In Chitwan Tharu, the lamino-alveolar $/ \overline{\mathrm{dz}} /$ converts to the lamino-alveolar [z] intervocalically: hai/dz/a 'malaria' is pronounced as hai[z]a and so/dz/a 'straight' as so[z]a (Leal 1972:20). In Haitian Creol / $/ \mathrm{d}_{3} /$ changes to [j] in the word-final position (Tinelli 1981).

Finally, it should be stressed that there are also processes attested in which voiced affricates emerge. However, these occur less frequent in comparison to the processes converting affricates into other sounds. They seem to be exceptions rather than a tendency. For example, in Montenegrin we observe the 
rise of the phoneme $/ \overline{\mathrm{dz}} /$ from /z/: /z/eleno $\rightarrow / \overline{\mathrm{dz}} /$ eleno 'green' or $/ \mathrm{z} / \mathrm{ubi} \rightarrow$ /dz/ubi 'teeth' (Greenberg 2000:298).

In summary, the processes presented above confirm certain instability of sibilant voiced affricates. The spectrum of the segments to which the affricates convert varies from devoiced affricates, sequences of stops and fricatives, voiced fricatives up to glides. Several of the changes presented are context-free, thereby highlighting marked properties of the voiced affricates.

\section{$4 \quad$ Typology of voicing}

The conclusions presented above prompt the question to what extent we can talk about cross-linguistic generalizations, and how the conclusions relate to other coronal sound classes such as coronal stops and fricatives.

Figure 1 presents frequency of occurrence of voiced and voiceless coronal obstruents. It is based on the UCLA Phonological Segment Inventory Database (Maddieson \& Precoda 1992) which includes the phonemic inventories of 451 languages.

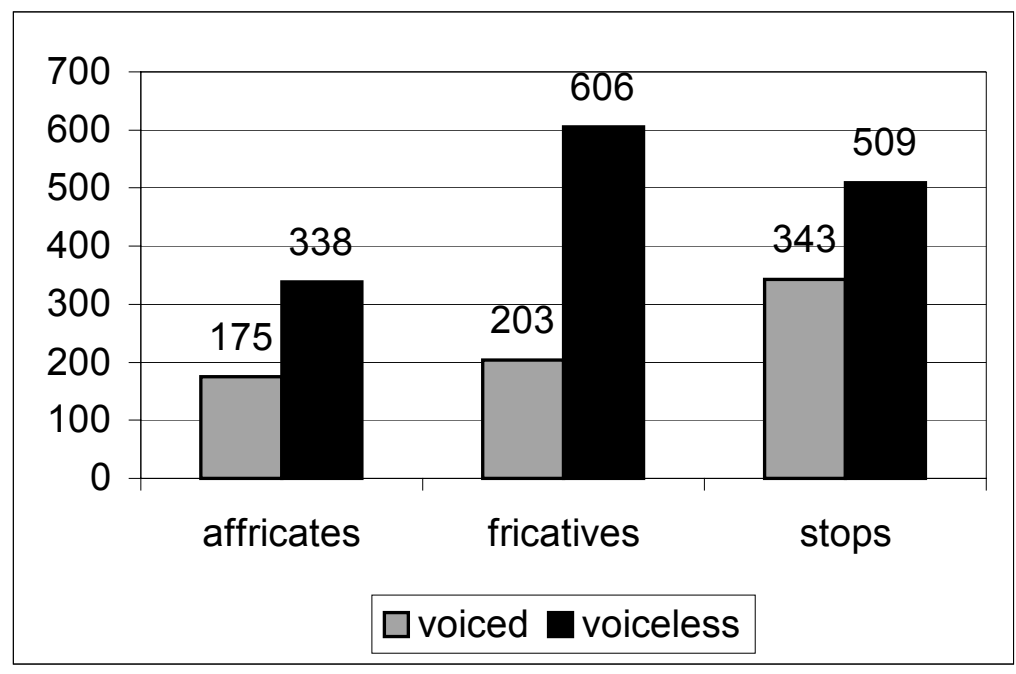

Figure 1: Frequency of occurrence of voiced and voiceless obstruents based on the UPSID database.

In all three classes, i.e. affricates, fricatives and stops, it is the voiceless segment that occurs more frequently than the voiced one. Thus, the conclusion can be drawn that the inherent properties of voicing including the articulation, aerodynamic conditions and laryngeal-oral coordination are responsible for the asymmetry.

How do these properties look in particular? Starting with the general aerodynamic properties of voicing, it is well known that in order to maintain 
vocal fold vibration, the supraglottal pressure must be lower than the subglottal pressure. It is assumed that this pressure drop should be greater than the threshold of voicing, i.e. $2000 \mathrm{dyn} / \mathrm{cm} 2(200 \mathrm{~Pa})$, in order to sustain vocal fold vibration; see Ladefoged (1964). The subglottal pressure building up below the glottis affects the lower parts of the adduced vocal folds initiating the vibration. Maintaining the pressure difference is especially difficult in stops due to the closure leading to an increase in the supraglottal pressure. To secure voicing throughout the closed phase or the final part of it, the volume of the vocal tract must expand so that the pressure will not build up too quickly. There are different strategies which enable the cavity above the glottis to be expanded. These include tissue compliance, muscularly actuated enlargement of the supraglottal cavity, the opening of the velopharyngeal port as well as jaw movements (see e.g Westbury 1983; for jaw movements see Mooshammer et al. 2007). All these manoeuvres are used to different extents by speakers in the production of voiced plosives. By contrast, voiceless plosives do not need an enlargement of the oral cavity as the vocal folds - being open - do not vibrate during their production.

In voiced sibilant fricatives, as observed by Ohala (1983), the problem of cumulating the air during the constriction phase with the risk of quenching voicing should disappear as the air continuously flows during the fricative articulation. However, this is not the case - as stressed by Ohala - because the turbulence characteristic of fricatives requires a high oral pressure. In other words, during the production of fricatives two conflicting conditions have to be fulfilled at the same time: a low oral pressure for maintaining voicing and a high oral pressure ensuring sufficient air velocity for creating frication. In addition, it is also observed that the opening of the glottis is coordinated with the supraglottal constriction so that the latter has to be smaller than the former to assure the production of the turbulence, see e.g. Scully et al. (1992).

Considering this issue in more detail, it should be noted that the emergence of the frication (turbulence) is generally determined by the flow rate, which depends on (i) the area of the constriction (A) and (ii) the difference in pressure between the two cavities on both sides of the constriction $\left(\Delta \mathrm{P}_{\mathrm{c}}\right)$. This means that the increasing pressure difference and the shrinking of the area of constriction leads to increased airflow rate, and consequently more turbulent airflow $(\mathrm{U}=\mathrm{A}$ $(\Delta \mathrm{P})^{0.5}$ ) (Solé 2003:2761). If the fricative is voiced, a pressure drop across the glottis is additionally required $\left(\Delta \mathrm{P}_{\mathrm{g}}\right)$.

Figure 2 shows the allowable range of aerodynamic variation for voiced fricatives as estimated from aerodynamic data (adapted from Solé 2002:370). 


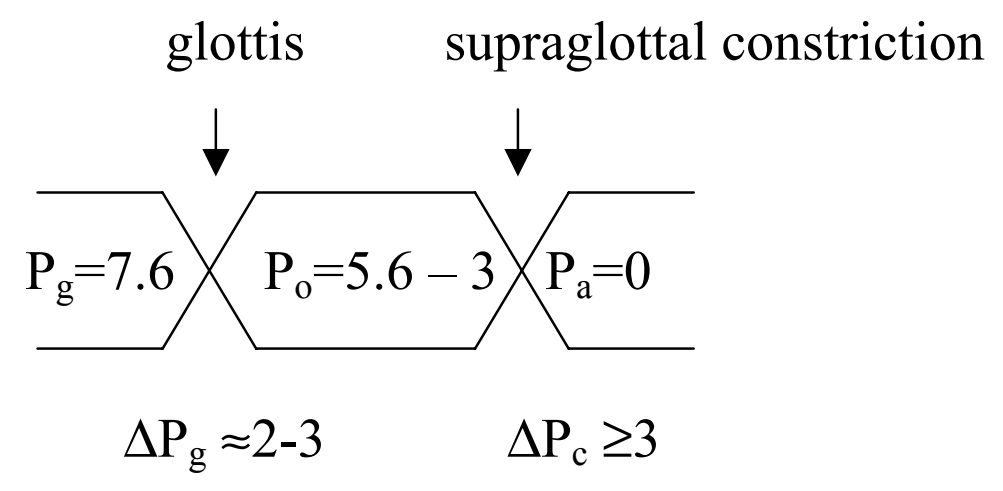

Figure 2: Estimated aerodynamic range for voiced fricatives.

The model presented in Figure 2 illustrates how voiced sibilants are constrained by aerodynamic conditions. Solé (1998) estimates a subglottal pressure $\left(\mathrm{P}_{\mathrm{s}}\right)$ of $7.6 \mathrm{~cm} \mathrm{H}_{2} \mathrm{O}$ in the production of a voiced sibilant. The pressure drop across the glottis should be of at least 2-3 $\mathrm{cm} \mathrm{H}_{2} \mathrm{O}$, which leaves an oral (supraglottal) pressure of at most $5.6 \mathrm{~cm} \mathrm{H} \mathrm{H}_{2} 0\left(\Delta \mathrm{P}_{\mathrm{g}}=\mathrm{P}_{\mathrm{g}}-\mathrm{P}_{\mathrm{o}}\right)$. The airflow then passes a supraglottal constriction, where turbulence is created. At this point, a pressure drop of approximately $3 \mathrm{~cm} \mathrm{H} \mathrm{H}_{2} \mathrm{O}$ creates frication. If this requirement is not met, the production of turbulence ceases; see Catford (1977), Ohala, Solé \& Ying (1998), Stevens (1998).

Let us proceed to affricates, the main subject of interest. Their aerodynamics and articulation are even more complex than those of voiced plosives. This follows from the fact that the plosive is released into a voiced fricative, which in turn requires additional effort to maintain the voicing as described above. Importantly, we could hypothesize that the precise aerodynamic conditions required for the voiced fricative are partly hampered by the increasing air pressure in the stop part (see the discussion in section 5).

What does the articulatory complexity of affricates in fact mean? The main distinction between an affricate and a stop is that the release of the former is prolonged in the form of friction. A stop is inherently fricated, especially if it is followed by a high vocoid, but the frication length is too short to be perceived as a fricative component. In affricates, on the other hand, the frication is considerably longer, constituting the most prominent part of the affricates from the perceptual point of view.

Wierzchowska (1980:100) presents cinetracings of the Polish affricate [tc] which clearly shows its two phases: the closure, and the (fricative) release. The $\mathrm{x}$-ray tracings in Figure 4 illustrate that the tongue blade touches a postalveolar place of articulation (tracings 2, 3, and 4), and then, during the release, a fricative is created (tracings 5 and 6). 

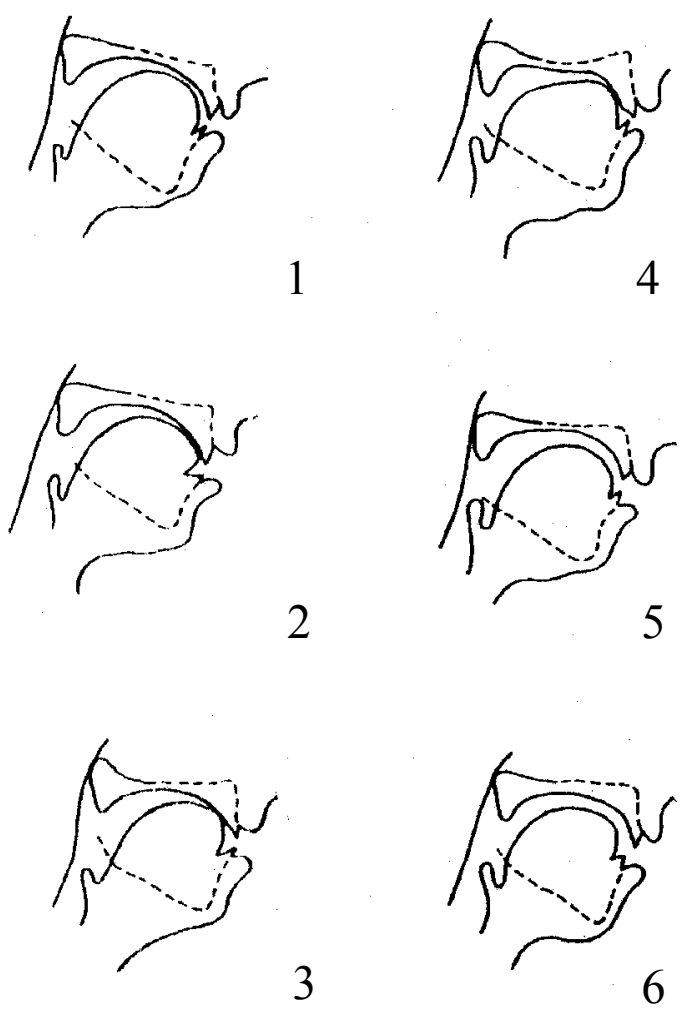

Figure 3: Cinetracings of the Polish affricate $[\overleftarrow{\mathrm{t} \epsilon}]$ (Wierzchowska 1980:100).

Stevens (1993a) notices that the release mechanism for an affricate differs from that for a stop consonant. This is due to the complexity of the affricate constriction, which consists of two parts: an anterior $\left(\mathrm{A}_{1}\right)$ and a posterior section $\left(A_{2}\right)$. See the schematic model of the vocal tract for the English affricate [ [t] presented in Figure 4. (Stevens 1993a:33).

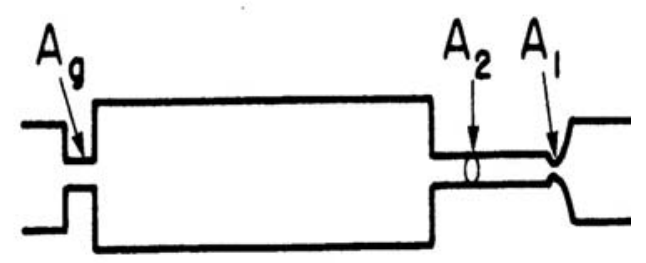

$\mathrm{A}_{\mathrm{g}}$ : the cross-sectional area of the glottal opening

$\mathrm{A}_{2}$ : frication part

$\mathrm{A}_{1}$ : plosive constriction

Figure 4: A schematic model of the vocal tract for the English affricate $[\widehat{\mathrm{t}}]$. 
Both components $A_{1}$ and $A_{2}$ can be manipulated independently. If a consonant is released, then the anterior section increases, whereas the posterior part remains unchanged for a few milliseconds. After this, a slow increase in the area $\mathrm{A}_{2}$ takes place. An important difference between the two sections is that the initial release is rapid while the posterior part is maintained longer, which is reflected in a longer fricative component of the affricate.

Stevens (1993b) also notices that the tongue shape is different in both components. This is shown in Figure 5, where the midsagittal section of the vocal tract is illustrated prior to the initial release of the stop component $[\widehat{t} \mathrm{t}]$ (dashed line) and 20-30 ms following the release (solid line) (Stevens 1993b:35).

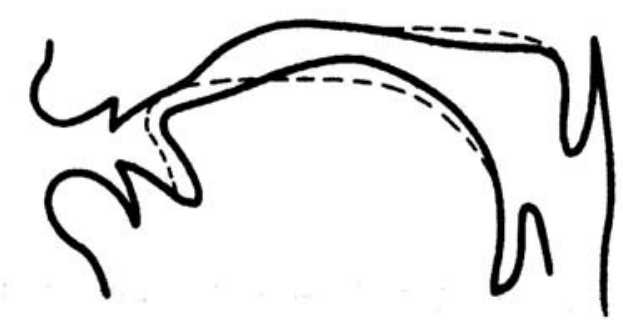

Figure 5: The midsagittal section of the vocal tract during the articulation of [t] $]$.

As can be inferred from Figure 5, the tongue blade and the tongue body behind the closure is depressed in comparison to its position for the fricative component. This can be explained by aerodynamic conditions, due to which the downward displacement of the tongue blade and the tongue body by the increased air pressure on the tongue surface during the closed phase is caused. At the moment when the closure is released, the air pressure decreases and the tongue moves upward; see Svirsky et al. (1992). As a consequence, the following fricative component should be articulated at a different place of articulation than the stop part.

However, it seems that the fast change from a closure where the tongue tip/tongue blade touches the palate to a constriction formed by the lateral parts of the tongue poses a challenge as the different articulatory gestures should be executed very quickly and precise in order to form an appropriate supralaryngeal constriction.

Ladefoged \& Wu (1984:272) notice some small but systematic differences between the affricates and the fricatives when investigating Pekingese sibilants

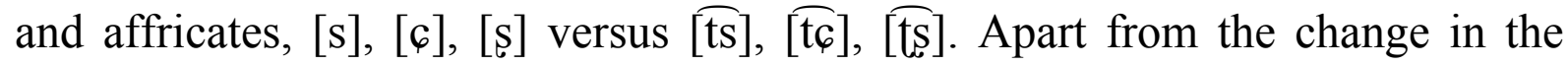
tongue tip or blade required for making the stop preceding the fricative, the body of the tongue changes its position. It is often slightly higher during the stop than 
during the fricative component. ${ }^{2}$ Apart from these small disparities, the affricates and the corresponding fricatives share the same place of articulation.

In summary, voiced affricates are less preferred than voiceless ones because two different conditions must be maintained in their production. These are listed in (1).

(1) (i) enlargement of the vocal tract cavity for maintaining voicing of the plosive;

(ii) fulfilment of two conflicting conditions simultaneously in the fricative release: a low oral pressure for maintaining voicing and a high oral pressure ensuring sufficient air velocity for creating frication.

Taking into consideration all facts listed above, it is hypothesized that the aerodynamic conditions attested in voiced affricates are more complex than in the production of voiced stops and voiced fricatives (see also Dixit \& Brown 1985 and König \& Fuchs 2007 for voiceless affricates). On the basis of experimental data consisting of Polish fully voiced affricates it will be shown that the fricative component of affricates is often exposed to devoicing due to the high pressure peak in the closure phase; see the presentation and discussion of the results in the next section.

\section{Experimental evidence}

\subsection{Experimental design}

The goal of the experiment is not only to get a better insight into the aerodynamics of voiced affricates in contrast to voiceless ones, but also to compare aerodynamic conditions in the production of stops, fricatives and affricates. For this purpose, three simultaneous recordings were obtained: (i) oropharyngeal pressure changes, (ii) airflow at the mouth, and (iii) audio-signal.

All recordings were obtained by using PCquirer (version 8.9.8.6.). The audio-signal was recorded at a sampling rate of $22500 \mathrm{~Hz}$ for the oropharyngeal pressure and of $2750 \mathrm{~Hz}$ for the airflow. The data were analysed by PCquirer. ${ }^{3}$

Four native speakers of Polish (two female and two male) took part in the experiment. Each subject was equipped with a Rothenberg mask and

2 See Figure 5 for a different positioning of the tongue body during the production of English $\left.\widetilde{\left[\mathrm{t} \int\right.}\right]$.

3 One of the disadvantages of using a Rothenberg mask is the rather weak acoustic quality. 
additionally a piezoresistive pressure transducer was glued on the back part of the palate (Endevco 8507C-2) to measure intraoral pressure differences.

The material consisted of words containing coronal voiced and voiceless obstruents: stops $/ \mathrm{t} d /$, fricatives $/ \mathrm{s} \mathrm{z} 6 \mathrm{z} /$ and affricates $/ \mathrm{ts}_{\mathrm{dz}} \overline{\mathrm{tc}} \overline{\mathrm{d}} \mathrm{T} /{ }^{4}$, see Table 5 . The obstruents appeared either in the intervocalic a a context or in the wordinitial prevocalic _a context. All words were bisyllabic with a stress falling on the first syllable. The subjects were asked to read all presented words embedded in a frame sentence Powiedziała ... do niego 'She said ... to him' and to repeat each sentence five times. The sentences were given in a randomized order.

Table 5: Polish words used in the experiment.

\begin{tabular}{|c|c|c|}
\hline & initial & medial \\
\hline $\begin{array}{l}/ \mathrm{d} / \\
/ \mathrm{t} /\end{array}$ & $\begin{array}{l}\text { /d/ata 'date' } \\
\text { /t/aca 'tray' }\end{array}$ & $\begin{array}{l}\mathrm{ra} / \mathrm{t} / \mathrm{a} \text { 'installment' } \\
\mathrm{ra} / \mathrm{d} / \mathrm{a} \text { 'advice' }\end{array}$ \\
\hline $\begin{array}{l}\mid \mathrm{z} / \\
/ \mathrm{s} / \\
\mid \mathrm{C} / \\
\mid \mathrm{z} /\end{array}$ & $\begin{array}{l}\text { /z/araz 'in a moment' } \\
\text { /s/arna 'roe dear' } \\
\text { /6/ara 'sulfur' } \\
\text { /z/arnka 'grain' pl. }\end{array}$ & $\begin{array}{l}\mathrm{ka} / \mathrm{s} / \mathrm{a} \text { 'cash' } \\
\mathrm{ga} / \mathrm{z} / \mathrm{a} \text { 'gauze' } \\
\mathrm{Ka} / \mathrm{c} / \mathrm{a} \text { proper name } \\
\mathrm{Ka} / \mathrm{z} / \mathrm{a} \text { proper name }\end{array}$ \\
\hline $\begin{array}{l}/ \overparen{\mathrm{dz}} / \\
\overparen{\mid \mathrm{ts}} / \\
\mid \overparen{\mathrm{dz}} / \\
\mid \overline{\mathrm{tc}} /\end{array}$ & 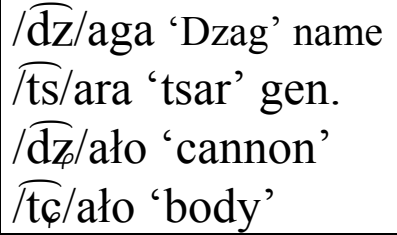 & $\begin{array}{l}\mathrm{sa} / \overparen{\mathrm{dz}} / \mathrm{a} \text { 'soot' } \\
\mathrm{ta} / \mathrm{ts} / \mathrm{a} \text { 'tray' } \\
\mathrm{na} / \widetilde{\mathrm{dz}} / \mathrm{ac} \text { 'to stuff' } \\
\text { bra/ } / \mathrm{tc} / \mathrm{a} \text { 'brother' pl. }\end{array}$ \\
\hline
\end{tabular}

The data were normalized for baseline shifts by setting the zero line in accordance with the closure phase in the airflow data and for the air pressure measurements in accordance with the pressure in a vowel [a]. Three parameters were measured in the segments:

(i) airflow peak

(ii) air pressure peak

(iii) duration of the components (stop and fricative phase in the case of affricates)

In Figure 6 the measurement points are shown for /ata/ excerpted from rata 'installment'.

4 Polish retroflex affricates $\overparen{\mathrm{ts}} \overline{\mathrm{dz}} /$ were not considered due to the lack of the appropriate test words. 


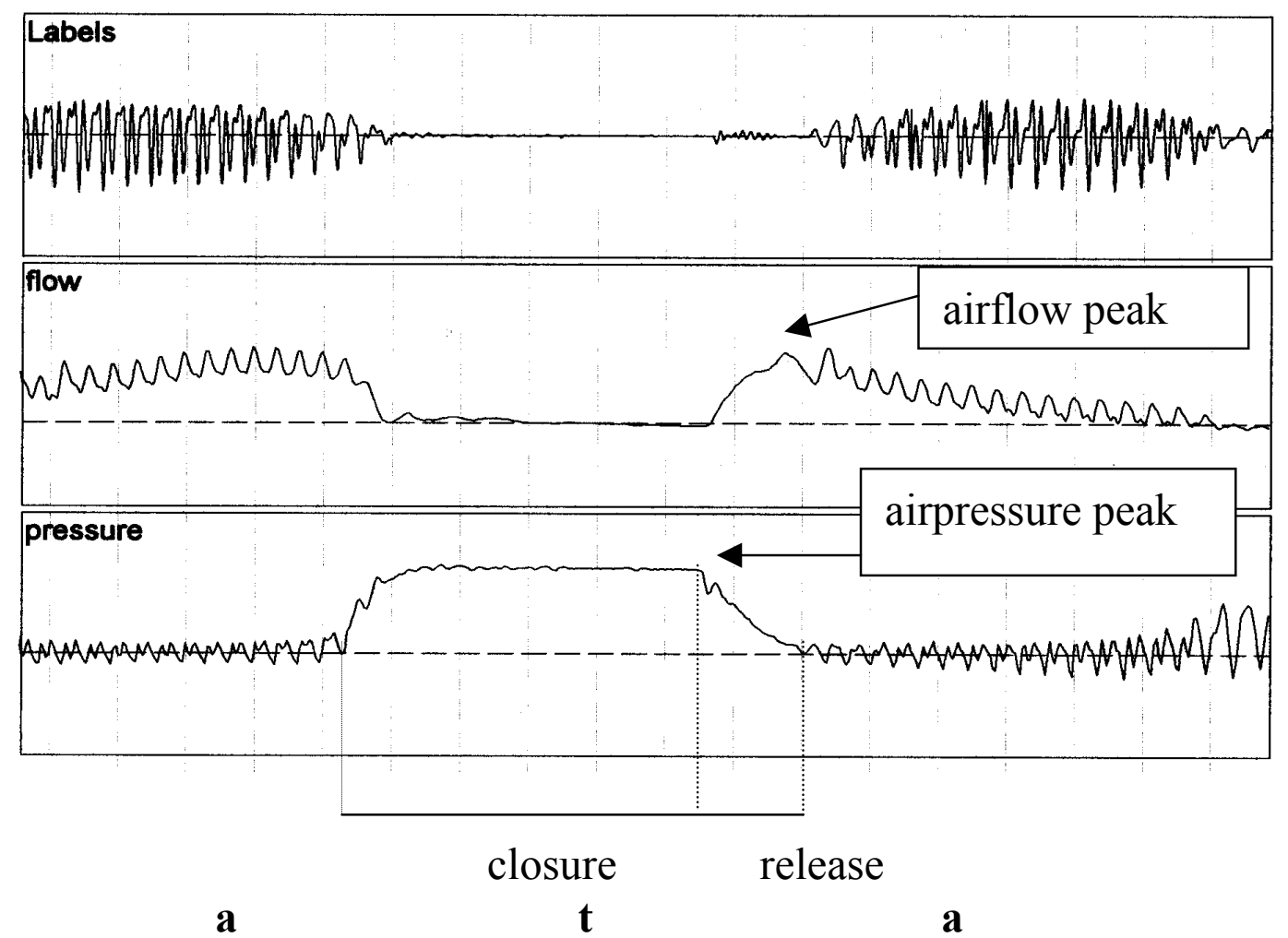

Figure 6: Measurement points in [t] excerpted from rata.

\subsection{Results}

The following discussion is focussed on the results of air pressure measurements which appear as the most relevant for the purposes of the present study. The comparison between voiced and voiceless affricates is of particular importance. Before presenting the results some discussion of the data is in order. Figure 7 illustrates how voiceless affricates are typically realized in the intervocalic position by Polish speakers.

In the realization of the closure phase of [ts] there is no airflow in contrast to the frication phase where the airflow is rising. As far as the air pressure is concerned, it is very high in the closure phase and diminishes in the frication phase.

The aerodynamics of the voiced affricates is notably different from their voiceless counterparts, as illustrated by Figure 8 . The voiced affricate [ $\overline{\mathrm{dz}}$ ] shows voicing throughout the whole segment. Therefore, it is difficult to determine where the boundary between closure and frication phase is. The airflow is nearly 0 and it slightly rises in the frication phase. Regarding the air pressure, it is higher in the closure phase and it decreases in the frication phase. The main difference between voiceless and voiced affricates is not only the amount and level of air pressure (see below) but the fact that air pressure varies 
throughout both the closure phase and the frication phase, indicating the vibration of the vocal folds.

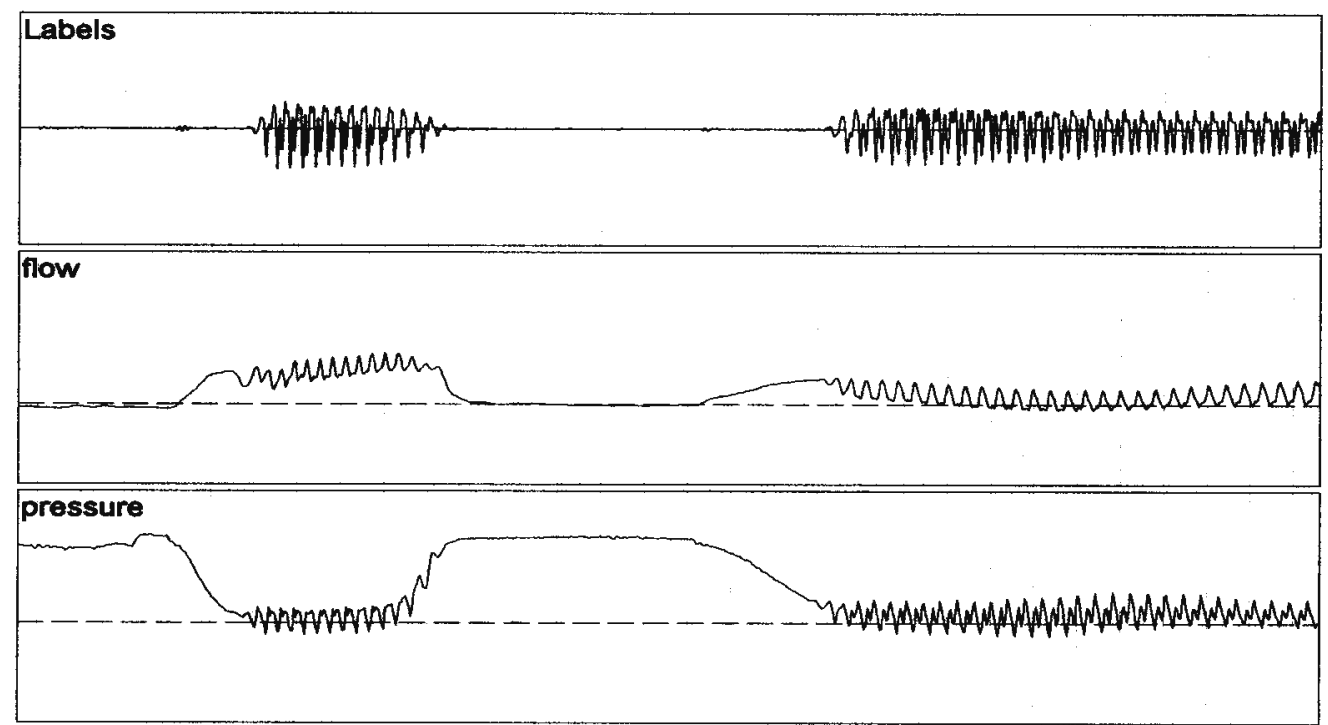

Figure 7: [ătsa] excerpted from cara.

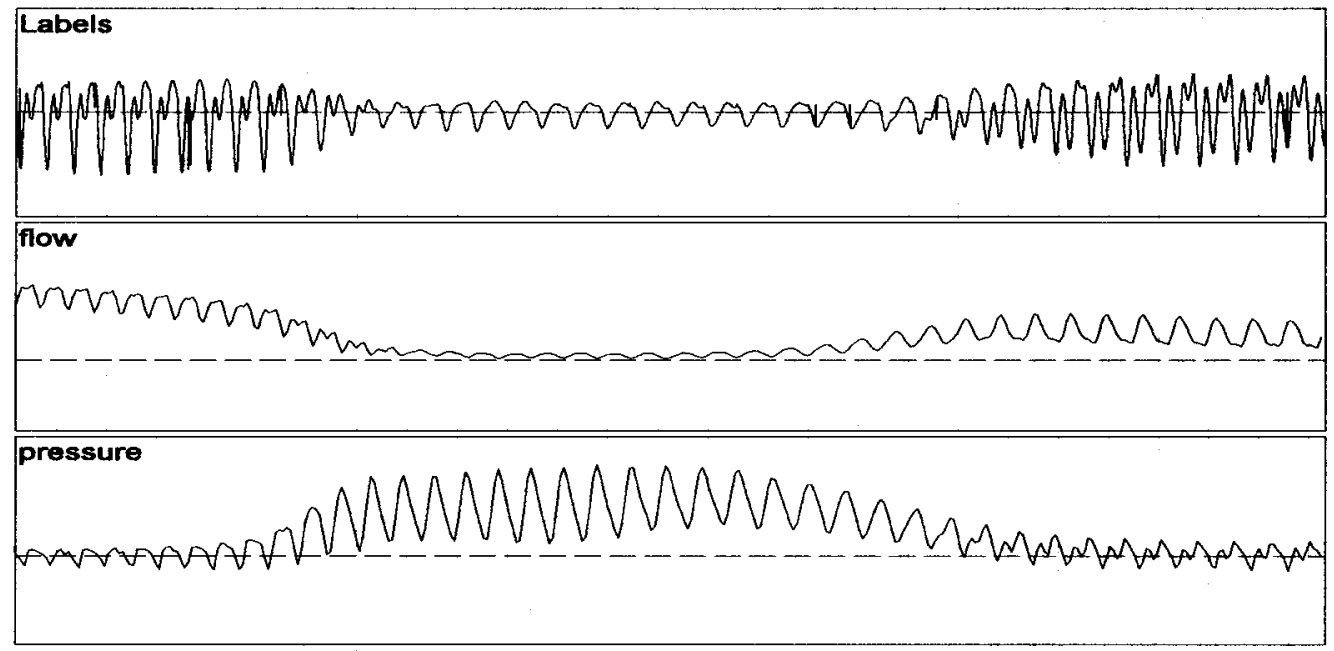

Figure 8: [ađ̄za] excerpted from sadza.

Let us proceed to the results. Figure 9 presents average air pressure peak values as obtained for individual speakers. 


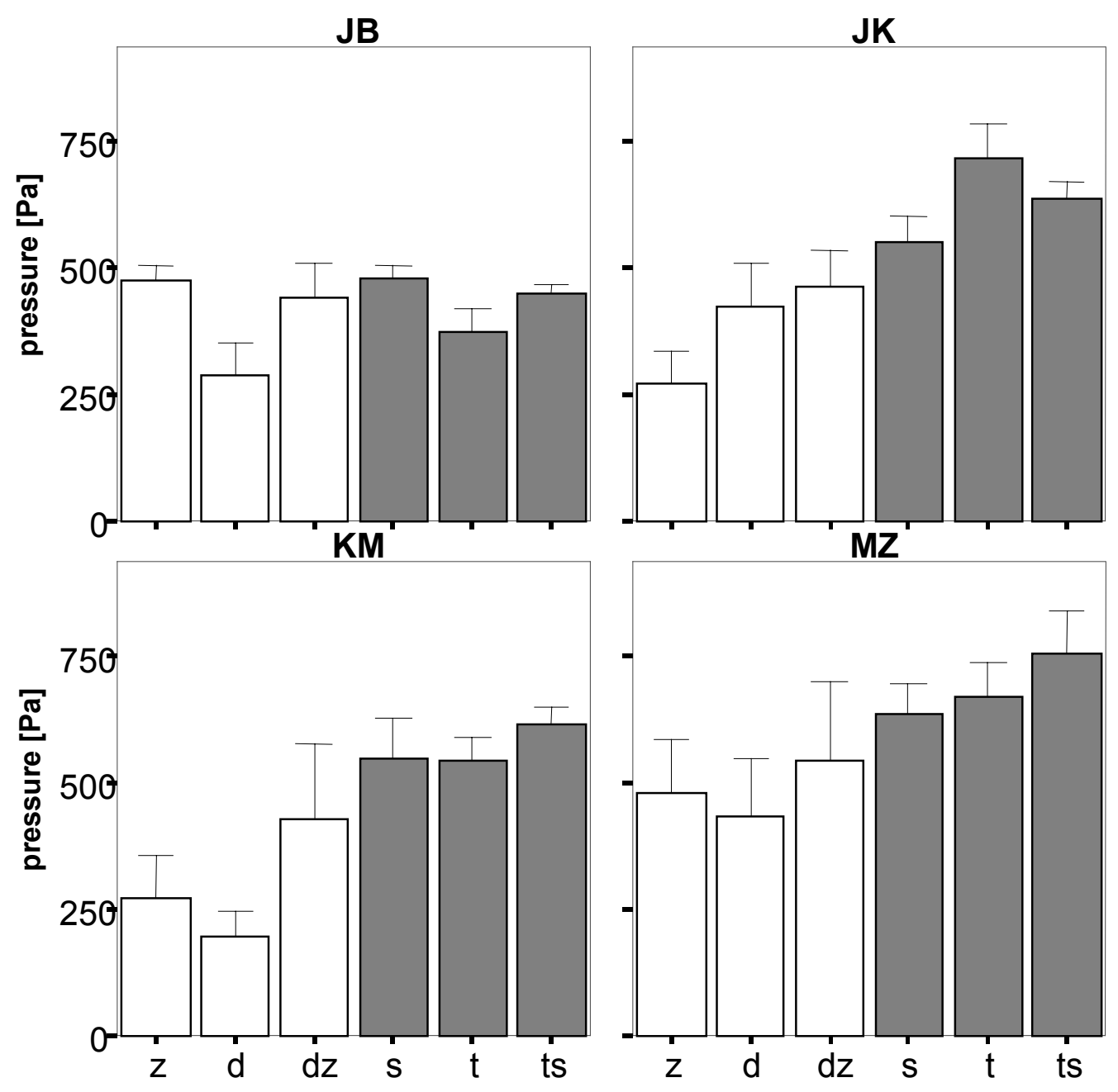

Figure 9: Bar plots showing average air pressure peak values with standard error as obtained for individual speakers (subplots); grey bars $=$ voiceless phonemes, white bars =voiced phonemes.

The results show that for three speakers, JK, KM and MZ, the peaks values for voiceless segments are significantly higher than for the corresponding voiced affricates. The only exception is speaker JB in whose pronunciation the air pressure peaks in voiced items are as high as in voiceless items. A closer inspection of the data reveals, however, that in some cases the affricate especially its fricative part - is devoiced, i.e. it does not show voicing. Such realizations appeared in the intervocalic position, but especially in the wordinitial position, as exemplified in Figure 10. They have also been found occasionally in the pronunciation of other speakers. 


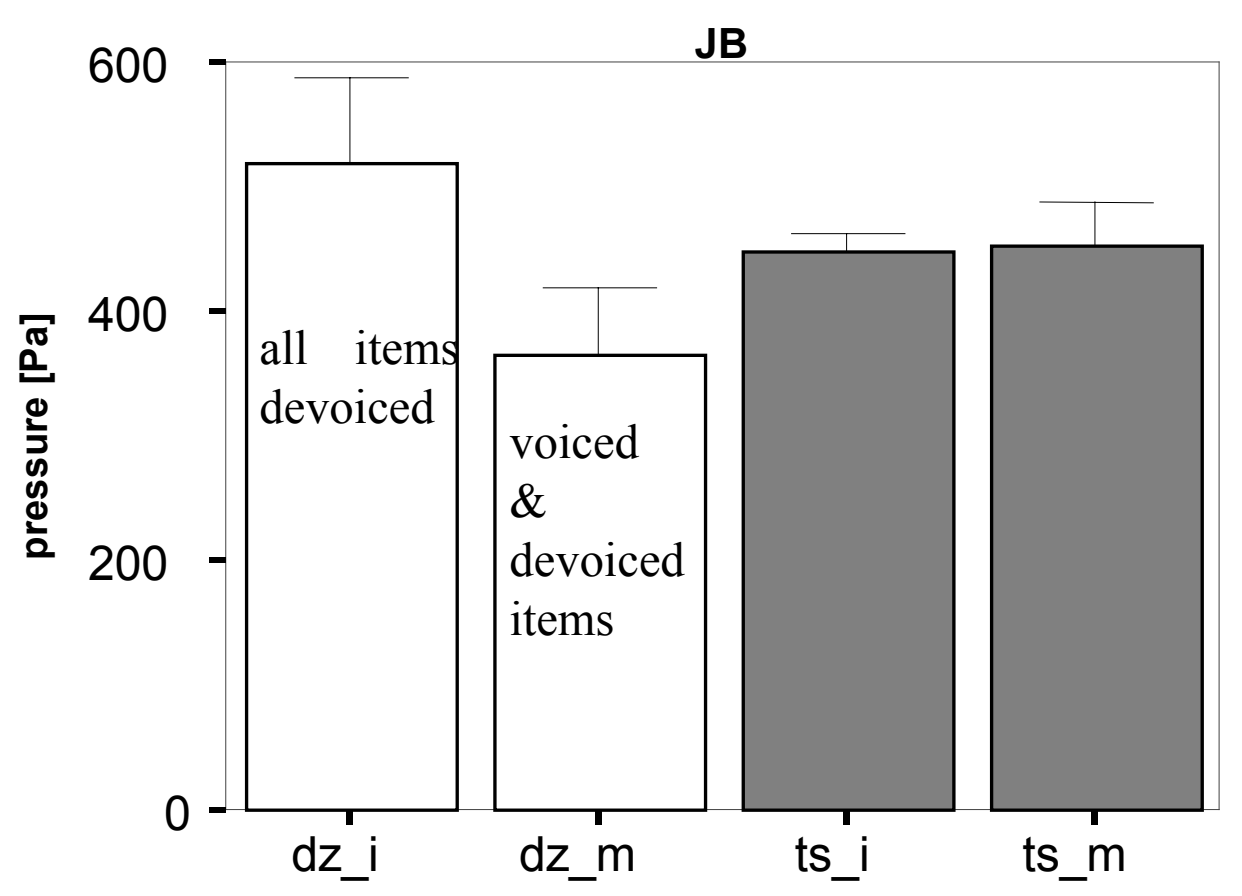

Figure 10: Bar plots showing average air pressure peak values and standard error as obtained for affricates $[\overline{\mathrm{dz}}]$ (white bars) and $\widetilde{\mathrm{ts}}]$ (grey bars) in wordinitial (_i) and word-medial position (_m) by speaker JB.

The air pressure profile of $[\overline{\mathrm{dz}}]$ frequently found in the pronunciation of speaker JB (see Figure 101) and occasionally in the pronunciation of other speakers provides a possible answer as to why voiced affricates are devoiced. It seems that in the production of affricates an air pressure conflict occurs: on the one hand, the pressure naturally rises in the closure phase, and on the other hand, it has to be lower for maintaining voicing in the closure and in the frication phase. But, at some point the air pressure in the closure reaches the point where the voicing ceases. It appears to be difficult to balance the pressures in both phases. The difficulty is increased by the fact that the frication phase also needs a higher pressure for creating turbulence (Ohala 1983). Hence, in the production of voiced affricates a balance has to be reached between (i) raising air pressure in the closure, (ii) lower air pressure in the frication phase which is required for maintaining voicing and (iii) high air pressure in the frication phase required for creating turbulence. It also appears that the word-initial position is of special difficulty for producing voiced affricates which could be attributed to observation (i) and to the fact that the initial position is always long which favours devoicing. In other contexts, e.g. in the intervocalic position, the air pressure does not rise so significantly. An indirect piece of evidence in favour of 
this proposal is the fact that the intervocalic context (but not the word-initial one) favors voicing cross-linguistically.

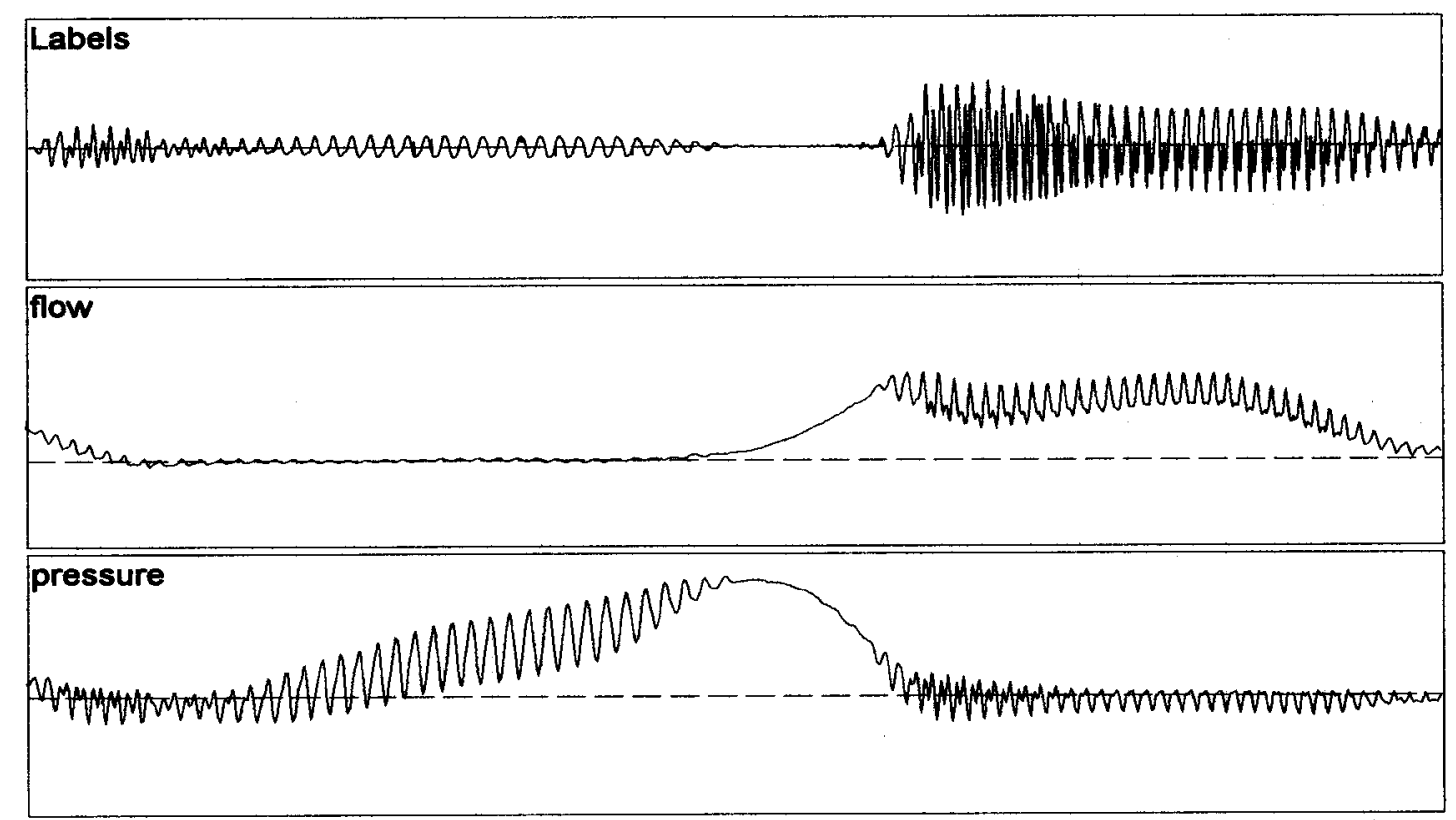

Figure 11: Devoicing in $[\overline{\mathrm{dz}}]$ in word-initial position.

Other results are in line with studies examining the difference between voiced and voiceless items, namely that the airflow peak in voiced items is consistently lower than the corresponding peak in voiceless items. This is due to the wider glottal opening in the voiceless items; see Figure 12.

The duration measurements show that (i) the closure duration is significantly longer in voiced and voiceless affricates than the frication duration and (ii) more specifically, the closure of the voiceless affricates is significantly longer than the closure of voiced affricates (see Figure 13). The latter conclusion is drawn for all speakers apart from JB, whose affricates are devoiced, as discussed above. Regarding the frication duration, it holds for all four speakers that the frication lasts longer in voiceless affricates than in voiced ones. The results are consistent with those obtained by Dogil \& Jessen (1989) and Zygis (2006). 


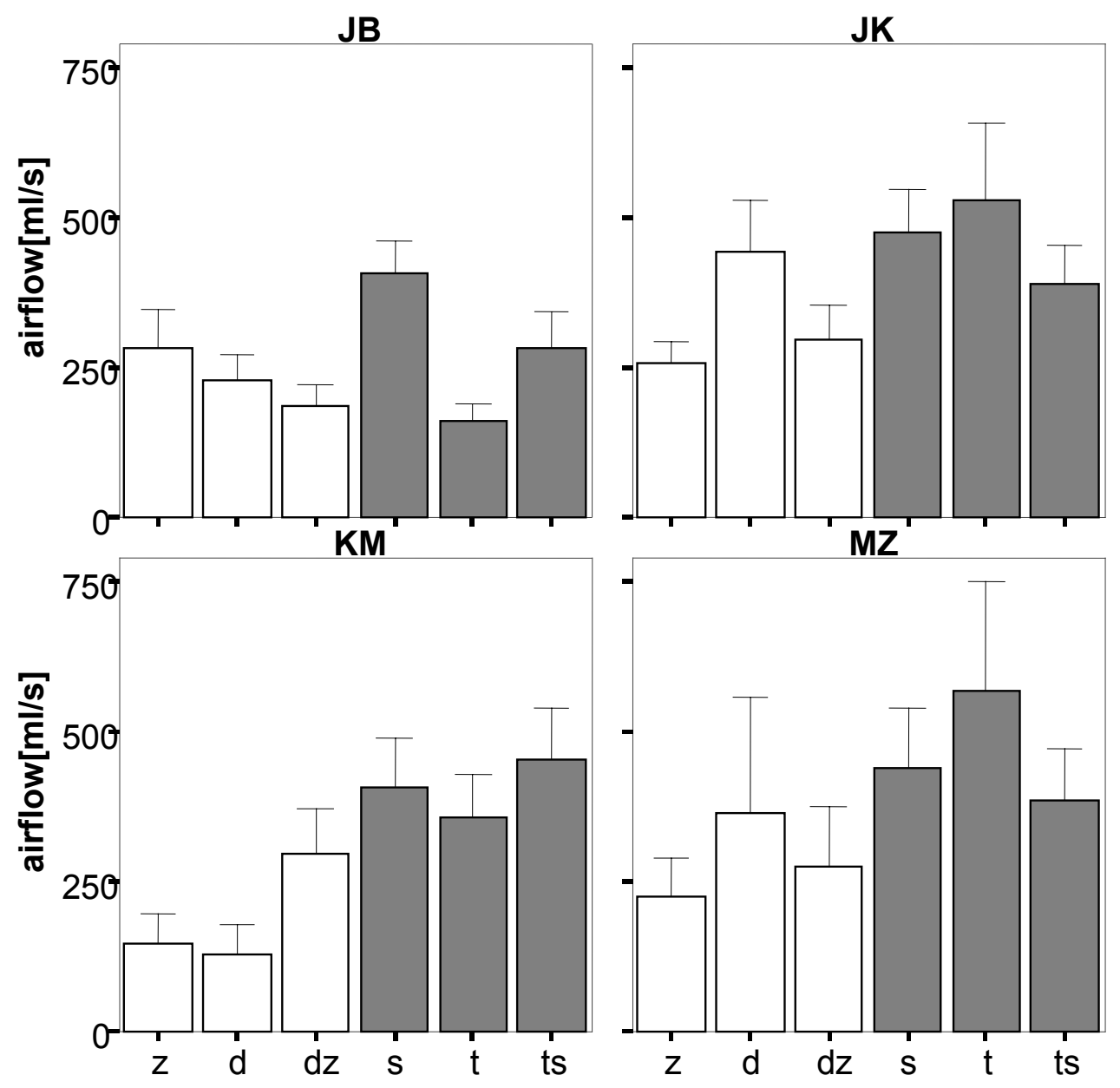

Figure 12: Bar plots showing average airflow peak values and standard error as obtained by individual speakers (subplots); grey bars $=$ voiceless phonemes, white bars $=$ voiced phonemes. 

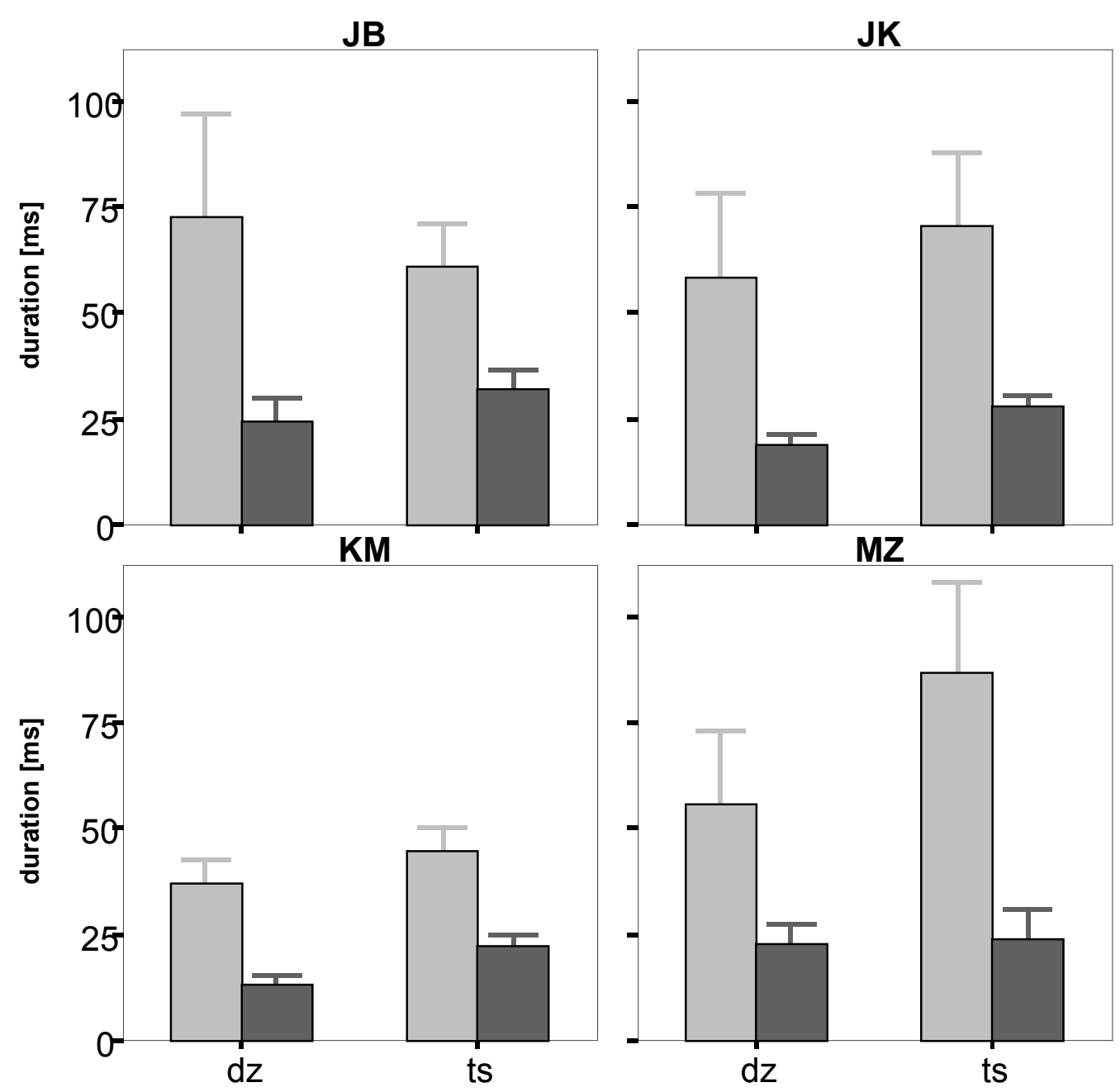

Figure 13: Bar plots with standard error showing average values of closure and frication duration for individual speakers (subplots); grey bars= closure duration, black bars $=$ frication duration .

In summary, the results presented in this section, especially those related to air pressure measurements, provide a possible answer as to why voiced affricates are avoided. It is namely the complexity of air pressure relations which are inherently antagonistic in the frication phase and aggravated by the raising air pressure in the closure phase, especially in the word-initial position.

\section{Conclusion}

This paper reveals that several typologically unrelated languages share the tendency to avoid voiced sibilant affricates. In the phonemic inventories of Slavic, Romance, Germanic and other languages, a phonemic gap is attested: voiced coronal affricates do not occur while their voiceless counterparts do. In several of these inventories, stops and fricatives create a contrast with respect to 
voicing as well. The avoidance of voiced affricates is supported by examples from phonological processes in which the existing voiced affricates change to other sounds.

It has been argued that this cross-linguistic tendency is to be attributed to the articulatory and aerodynamic complexity of affricates. As evidenced by the experimental results, the frication component of affricates is subject to devoicing. This is due to the air pressure rise in the stop part which is too high to maintain optimal conditions for fricative voicing.

This first attempt at explaining the avoidance of voiced affricate should be deepened by EPG and transillumination studies in order to gain more insight into the laryngeal-oral coordination. Despite the well-known fact that the glottis is more open in voiced fricatives than in voiced stops it remains to be seen how the opening of the vocal folds is coordinated with the supralaryngeal articulation in voiced affricates. Finally, this study poses a question as to why languages choose different sounds when dispensing with voiced affricates. I leave this question open for further study.

\section{ACKNOWLEGMENTS}

I would like to thank Susanne Fuchs, Tracy Alan Hall, Bernd PompinoMarschall, John Ohala and Jaye Padgett for valuable comments on earlier versions of this paper. Jörg Dreyer provided an excellent technical support. This research has been supported by the DFG project GWZ-4/11-1-P2.

\section{References}

Avery, P. \& W. Idsardi (2001). Laryngeal dimensions, completion and enhancement. In: Hall, T. A. (ed.) Distinctive Feature Theory. Berlin: de Gruyter. 4-70.

Boersma, P. (1998). Functional Phonology. Den Haag: Holland Academic Press.

Catford, J. C. (1977). Fundamental Problems in Phonetics. Edinburgh: Edinburgh University Press.

Dalewska-Greń, H. (2002). Jezyki stowiańskie. Warszawa: Wydawnictwo Naukowe PWN.

Dixit, R.P. \& W.S. Brown (1985). Peak magnitudes of oral air flow during Hindi stops (plosives and affricates). Journal of Phonetics 13, 219-234.

Dogil, G. \& M. Jessen (1989). Phonologie in der Nähe Phonetik. Die Affrikaten im Polnischen und Deutschen. In: Prinzhorn, M. (ed.) Phonologie. Opladen: Westdeutscher Verlag. 223-279.

Gianneli, L. \& L. Savoia (1979). Indebolimento Consonantico in Toscana. Revista Italiana di Diallettologia 2, 23-58. 
Greenberg, R. (2000). The dialects of Macedonia and Montenegro: Random Linguistic Paralles or Evidence of a Sprachbund? Južnoslovenski filolog 56, 295-300.

Hall, T. A. (1992). Syllable Structure and Syllable-Related Processes in German. Tübingen: Max Niemeyer Verlag.

Holes, C. (1990). Gulf Arabic. Routledge: London.

Iverson, G. \& J. C. Salmons (1995). Aspiration and laryngeal representation in Germanic. Phonology 12, 369-396.

Iverson, G. \& J. C. Salmons (2003). Legacy specification in the laryngeal phonology of Dutch. Journal of Germanic Linguistics 15, 1-26.

Ivić, P. (1958). Die serbokroatischen Dialekte. Ihre Struktur und Entwicklung. Vol. 1: Allgemeines und die štokavische Dialektgruppe. 'S-Gravenhage: Mouton.

Kehrein, W. (2002). Phonological Representation and Phonetic Parsing: Affricates and Laryngeals. Tübingen: Max Niemeyer Verlag.

König, L.L. \& S. Fuchs (2007). The sensivity of intraoral pressure in consonants and consonant clusters to following vowel context in German. ICPhS 16, 641 - 644.

Kučera, H. (1961). The Phonology of Czech. The Hague: Mouton \& Co.

Ladefoged, P. (1964). Comment on 'Evaluation of methods of estimating subglottal air pressure'. Journal of Speech and Hearing Research 7, 291-292.

Ladefoged, P. \& W. Z. Wu (1984). Places of articulation: An investigation of Pekingese fricatives and affricates. Journal of Phonetics 12, 267-278.

Leal, D. (1972). Chitwan Tharu. Phonemic Summary. Kirtipur: Summer Institute of Linguistics and Institute of Nepal Studies Tribhuvan University.

Lieutard, H. (2004). Phonologie et morphologie du parler occitan de Graulhet (Tarn). Structure, contenu et rôle de la syllabe. Montpelhièr: CEO.

Lombardi, L. (1994). Laryngeal features and laryngeal neutralization. Lingua 98, 46-53.

Lombardi, L. (1999). Positional faithfulness and voicing assimilation in Optimality Theory. NLLT 17, 276-302.

Maddieson, I. (1984). Patterns of Sounds. Cambridge: Cambridge University Press.

Maddieson, I. \& K. Precoda (1992). UPSID and Phoneme. UCLA Phonological Segment Inventory DatabaseVersion 1.1.

Mooshammer, C., Geumann, A., Hoole, P., Alfonso, P., van Lieshout, P. \& S. Fuchs (2003). Coordination of lingual and mandibular gestures for different manners of articulation. In: Solé, M. J., Recasens, D. \& J. Romero (eds.) Proceedings of the 15th ICPhS, Barcelona. 81-84.

Mooshammer, C., Hoole, P. \& A. Geumann (2007). Jaw and order. Language and Speech 50, 145-176.

Ohala, J. J. (1983). The origin of sound patterns in vocal tract constraints. In: MacNeilage, P. F. (ed.) The Production of Speech. New York: Springer Verlag. 189-216. 
Ohala, J. J., Solé, M. J. \& G. Ying (1998). The controversy of nasalized fricatives. Proceedings of the 135th Meeting of the International Congress on Acoustics of Acoustical Society of America. Seattle, Washington. 2921-2922.

Schuster-Šewc, H. (1996 [21999]). Grammar of the Upper Sorbian Language. München: Lincom Europa.

Scully, C. et al. (1992). Analysis and simulation of speaker's aerodynamic and acoustic patterns for fricatives. Journal of Phonetics 20, 39-51.

Short, D. (1993). Czech. In: Comrie, B. \& G. G. Corbett (eds.) The Slavonic Languages. London: Routledge. 455-532.

Solé, M. (1998). Phonological universals: Trilling, voicing, and frication. Proceedings of the Twenty-Fourth Annual Meeting of the Berkeley Linguistics Society. 403-416.

Solé, M. (2002). Assimilatory processes and aerodynamic factors. In: Gussenhoven, C. \& N. Werner (eds.) Papers in Laboratory Phonology. Berlin: de Gruyter. 351-386.

Solé, M.-J. (2003). Aerodynamic characteristics of onset and coda fricatives. Proceedings of the 15th ICPhS, Barcelona. 2761-2764.

Steriade, D. (1997). Phonetics in Phonology: the Case of Laryngeal Neutralisation. Ms. UCLA.

Stevens, K. N. (1993a). Modelling affricate consonants. Speech Communication 13, 33-43.

Stevens, K. N. (1993b). Models for the production and acoustics of stop consonants. Speech Communication 13, 367-375.

Stevens, K. N. (1998). Acoustic Phonetics. Cambridge, MA: MIT Press.

Svirsky M. A., Stevens, K. N., Matthies, M. L. \& J. S. Perkell (1992). Tongue surface deformation during obstruent stop consonants. JASA 92, 2390.

Tinelli, H. (1981). Creole Phonology. The Hague: Mouton.

Westbury, J. R. (1983). Enlargement of the supraglottal cavity and its relation to stop consonant voicing. JASA 73, 1322-1336.

Wetzels, W. L. \& J. Mascaro (2001). The typology of voicing and devoicing. Language 77, 207-244.

Wierzchowska, B. (1980). Fonetyka i fonologia języka polskiego. Wrocław: Zakład Narodowy im. Ossolińskich: Wydawnictwo Polskiej Akademii Nauk.

Zilyns'kyj, I. (1979). A Phonetic Transcription of the Ukrainian Language. Cambridge, MA: Harvard University Press.

Zygis, M. (2006). Contrast Optimisation in Slavic Sibilant Systems. Habilitationsschrift. Humboldt-Universität zu Berlin. 